Islamic Statehood and Maqasid al-Shariah in Malaysia. A Zero-Sum Game? has the size and scope of an article, but resembles a pamphlet both in terms of format and contents. It raises a vital issue, not only in the Malaysian context, but, I would say, in the global Islamic discourse. In failing to discuss more explicitly how the maqāssid should be included in the discourse, the author runs, however, the risk of becoming another participant in the rhetorical game he is criticising both UMNO and PAS for. It is as if the author has laid down a conceptual framework for an analysis that we are nevertheless still waiting for. For instance, he lashes out at PAS's hudūd initiative, but fails to demonstrate how this initiative clashes with the maqāșid approach. After all, the proponents of the hudūd initiative may very well further the argument that these regulations are meant to protect the five key goals of the shari 'ah, as these are outlined by the author (pp. 34-5). Few Muslims would argue against Islam promoting general welfare and good values. That general message of the book is therefore easily brought home. The interesting argument, put forward in apt wordings, about the nature and scope of the Malaysian discourse in view of the maqāșid al-sharī'ah would however benefit from further substantiations.

\title{
Saim Kayadibi, Istihsān: The Doctrine of Juristic Preference in Islamic Law
} (Kuala Lumpur: Islamic Book Trust, 2010), 384 pp. ISBN: 9789675062476. US\$20.00

Eric Winkel International Institute of Advanced Islamic Studies (IAIS) Malaysia

I received this book for review right in time for this special issue on maqāsid, which is fitting, as the concept of istihsān is often interchangeable with maqāșid (p. 34), as in al-Ghazālī's description of mașlahah consisting of 'five essential values', which we tend to call today maqāșid or 'objectives'. The book is a complete and well-documented history of the term and the concept. As such, it is a necessary reference for anyone studying Islamic law. I found especially valuable the author's knowledge of the lineages in the 'schools of Sunnite jurisprudence', especially in the Hanafī 'school'. The book will help any student trying to situate the legal scholars over the centuries.

The author shows how the concept is linked to ijtihād and thereby affirms the open nature of the 'door of $i j t i h \bar{a} d$ '. The author gives us a list of scholars who provided qualifications for the mujtahid, but points out that al-Shātibī "ignored these lists and reduced the conditions of $i j t i h \bar{a} d$ to one comprehensive point: the precise comprehension of the maqāsid and in the light of this comprehension the ability to deduce rules from the sources" (p. 301). 
The author presents the very complicated and involved history of the concept in Islamic law in a clear narrative. However, there are areas when the reader needs more evaluation. For example, in the section on ijtihād by the Companions we follow some decisions made by 'Umar. Even though

Muslim men are allowed to marry women from among the People of the Book (Christian and Jewish women), as stated in the Qur'ān (5:6), 'Umar accepts this in principle, but he prohibited it because he believed it would be detrimental to Muslim women. In this example, we see conformity to maslahah, together with the principle of understanding and applying verses and hadith by considering all the naș. 'Umar has given a ruling that is in opposition to the general ruling of the naș in this special situation, according to the objective and spirit of the Sharī'ah. (p. 91)

This is certainly an important case and an evaluation is needed. What were the historical reactions to this over the centuries? Is there a connection between this and the Malaysian legal position on the matter of inter-marriage today? This case seems to be different from the decision not to cut the hand off the thief during famine, because in that case, the idea is that there is an unspoken precondition that the penalty is for the thief who knowingly steals something out of greed, not out of necessity. This might tie into the 'moratorium' called for by Tariq Ramadan. Many legal scholars rejected the Call vehemently, seeing it as a call to put aside a part of the law. Historically, and obviously, not every adulterer or thief was penalised. The reason is not because the authorities had put aside the $\operatorname{sharl}^{-}$' $h$ but because they were quick to let doubt (shubh) preclude the very serious penalty.

'Umar also did not apply the general ruling about conquered lands, leaving the land "in the hands of its owners" and levying taxes "to pay the wages of judges, officials and soldiers. The taxes would also be used to help widows, orphans and those in need; in this 'Umar was forward thinking, believing that these taxes would be for the benefit of future generations. In this example of ijtihäd, 'Umar has abandoned the general ruling and adopted a ruling that would implement the mașlahah for the future of the Muslims" (p. 93). Again, this is a very important case and needs to be evaluated, not only historically but for contemporary reference as well.

Both the concept and the author's descriptions go to the heart of the question of finding 'Islamic' solutions to problems. There are no clear answers, as evidenced by the intricate and wide-ranging debates over the centuries, but this book provides us with a map of Islamic law. 